\title{
Protection of Indigenous Peoples Law Based on the 1945 Constitution
}

\author{
Moh. Arif Hariyanto ${ }^{1}$, Azis Budianto ${ }^{2}$ \\ Borobudur University ${ }^{1,2}$ \\ \{ariefunboro@gmail.com¹,azis_budianto@borobudur.ac.id²
}

\begin{abstract}
The plurality in Indonesia is marked by the number of tribes that exist and inhabit its territory. Each tribe has a territory and customary laws that apply in the area. Many problems involve indigenous peoples about land, population, and governance issues, and lead to the marginalization of indigenous peoples. Through a normative approach, and using literature data related to the protection of indigenous peoples' laws based on the 1945 Constitution, it is found that the state recognizes, respects, and is responsible for indigenous peoples in the territory of Indonesia. The responsibility of the state is not only related to administration and its relationship with the state, but also to efforts to fulfill and protect the rights of indigenous peoples.
\end{abstract}

Keywords Indigenous Peoples; Legal Protection; The 1945 Constitution

\section{Introduction}

The presence of the Indonesian government for indigenous peoples is beginning to be felt. The welfare of Indigenous Peoples has become a serious concern in development in Indonesia. This is reflected in the fact that Indigenous Peoples have become a development priority as stated in the National Medium Term Development Plan (RPJMN). The Indonesian government has a strong legal basis for realizing social protection for Indigenous Peoples. This affirms that indigenous peoples and their traditional rights are recognized and respected by the state.

\section{Results and Discussions}

\subsection{Get to Know Indigenous Peoples}

Indigenous Peoples is a general term used to describe groups of people who share similar characteristics such as common origins, lands, territories, natural resources, and distinctive cultural identities. The issue of Indigenous People has also been a concern of the International Labor Organization (ILO) since the 1950s. The ILO uses the term Indigenous People as a designation for Indigenous entities. The United Nations Declaration on the Rights of Indigenous Peoples understands Indigenous People as a group that contributes to the diversity and richness of civilization, culture, and is the common heritage of human civilization. The 
United Nations (UN) defines Indigenous People as "a broad spectrum of social groups (including Indigenous Ethnic Minorities, Tribal Groups, and Schedules Tribes), namely groups that have a social and cultural identity that can be distinguished from the dominant society, which makes them not benefited in the development process. " Meanwhile, in Indonesia, there are various terms and definitions used to refer to Indigenous People.[1]

The Ministry of Social Affairs uses the term Remote Indigenous Community (KAT) based on Presidential Decree No. 111/1999 concerning Social Welfare Development for Remote Indigenous Communities. In the Presidential Decree, it is stated that what is meant by remote customary communities or those better known as isolated communities is a socio-cultural group that is local and scattered and has little or no involvement in social, economic and political networks and services. Several other terms and definitions are used to refer to the subject of Indigenous Peoples, including Indigenous Peoples or Rural Communities. Indigenous peoples generally live and live behind mountains or in valleys, in the middle of swamps, on the coast and in dense forests. Many of them have never had contact with the outside world. To maintain their life, they create systems and patterns of life that are harmonious with the conditions and availability of natural resources around the areas they live in. The decision-making system is managed by the customary leader and issues in general are decided by deliberation.

Judging from the historical background, the indigenous peoples in the Indonesian archipelago have very old historical and cultural backgrounds and are much older than the formation of a kingdom or state. Historically, indigenous peoples in Indonesia and the ethnicities that surround them, have actually been migrants from other regions in Southeast Asia. Culturally, they are included in the Austronesian cultural area, namely the culture of rice farmers, with community structures and ownership rights arranged collectively, especially ownership rights over customary land. In political life, some ethnic groups have succeeded in dominating other ethnicities and their territories, and forming traditional kingdoms, both local and regional in size.[2]

\subsection{Characteristics of Indigenous Peoples}

Indigenous peoples can be identified by their characteristics, which are as follows:[3]

a. There is an orderly society

b. Occupying a certain place

c. There are institutions

d. Having mutual wealth

e. The composition of the community is based on the relationship of a descendant or based on the regional environment

f. Live communally and in mutual cooperation.

In indigenous peoples, to achieve this welfare, they must have a government or leadership structure. In this case, they have full soverign over their territory (ulayat land) and through customary leaders who have full authority to manage, regulate and organize the relationships between residents and the natural surroundings. This aims to create a balanced relationship so that peace and prosperity of indigenous peoples can be realized. In the book De Commune Trek in bet Indonesische Rechtsleven, F.D. Hollenmann constructs 4 (four) general characteristics of indigenous peoples, namely:[4]

a. The magical nature of religious is defined as a mindset based on people's beliefs about the existence of something sacred. Before people come into contact with the religious legal system, this religiosity is manifested in a prologic way of thinking, animism, and 
belief in the unseen world. Society must maintain harmony between the real world and the inner world (the unseen world). After the public knows the system of religious law, religious feelings are manifested in the form of belief in God. People believe that every action whatever its form will always receive a reward and punishment from God according to the degree of change.

b. Communal character (commuun), society has the assumption that every individual, member of society is an integral part of society as a whole. It is believed that individual interests should appropriately be matched with the interests of society because no individual can be separated from society.

c. The concrete character is defined as a completely clear or tangible feature indicating that every legal relationship that occurs in society is not carried out secretly or vaguely.

d. The nature of cash (kontane handeling) means participation, especially in fulfilling achievements. Every achievement achievement is always contra-achievement which is given immediately / immediately.

\subsection{Content and Discussion}

In Indonesia, according to Sandra Moniaga, we should feel lucky with the existence of indigenous peoples who number more than a thousand communities. Their existence is a nation's wealth, because there are more than a thousand kinds of knowledge that they have developed. And, there are more than a thousand languages that have been used and can help develop the repertoire of Indonesian and many other things that they contribute.[5] Ade Saptomo, who stated that indigenous peoples are an autonomous community unit, that is, they regulate their life systems (law, politics, economy, etc.). He was born from and developed together, and is maintained by society itself.[6]

\subsection{Types of Indigenous Peoples}

Various Non-Governmental Organizations (NGOs) often also have their own terms and definitions related to Indigenous Peoples. The Indigenous Peoples Alliance of the Archipelago (AMAN) views Indigenous Peoples as a group of people who live based on their ancestral origins in a certain geographic area, have a distinctive socio-cultural and value system, have sovereignty over their land and natural resources and regulate and manage the sustainability of their life by law customary institutions. AMAN further divides the definition of Indigenous Peoples into 4 types with each type representing its own unique characteristics.[7]

\section{a) Indigenous People of Kanekes Type}

Kanekes positioned himself as the "Earth Hermit." They believe that they are a "chosen" group of people whose job is to preserve the earth by praying and living with concern. The choice of life that they are concerned about can be seen from their farming customs, clothing, consumption patterns, and so on.

\section{b) The Kasepuhan Type Indigenous Community}

These indigenous peoples are basically quite strict in maintaining and implementing their customs, but they still open up enough space for "commercial" relationships with the outside 
world. These social groups are socially unique, especially in relation to agrarian sources, in terms of the value systems adopted, myths, and origins.

\section{c) Natural Type Indigenous Peoples}

This type of indigenous people lives depending on nature (forests, rivers, sea, etc.). They developed a unique natural resource management system, but did not develop strict customs for housing or selection of plant species when compared to the Kanekes and Kasepuhan Indigenous Peoples.

\section{d) Waiting Type Indigenous Peoples}

Indigenous peoples of this type are those who have been "uprooted" from the "original" natural resource management system. This type of indigenous people is the result of colonization that has developed for hundreds of years. They call themselves watchmen.

The first three types of communities, arguably, are communities that are referred to by Law Number 41 of 1999 concerning Forestry as "Customary Law Communities," namely communities that still fulfill the following elements: (a) their communities are still in the form of an association ( rechts-gemeenschap); (b) there is an institution in the form of an apparatus of customary rulers; (c) there is a clear customary law area; (d) there are legal institutions and instruments, especially customary courts, which are still adhered to; (e) still collecting forest products in the surrounding forest area to fulfill their daily needs. Presidential Decree No. 111 of 1999 itself understands that indigenous peoples are characterized by:

a. The form of a small, closed, and homogeneous community.

b. Social institutions are based on kinship relations.

c. Generally geographically remote and relatively difficult to reach.

d. In general, they still live with a subsistence economic system. e. Simple equipment and technology.

e. Reliance on the environment and local natural resources is relatively high.

f. Limited access to social, economic and political services.

\subsection{Indigenous Peoples' Rights}

The Civil Society Coalition that oversaw the Indigenous Peoples Bill assesses that at least six rights of indigenous peoples are constantly being violated where these rights are inseparable (indivisibility) and inherent (inherent), and must be recognized for the human achievement of society custom. These rights are:[8]

\section{a) Rights to Customary Territory}

Customary territory is the living space of the customary community which is the place for the existence of an indigenous community entity whose control, management and utilization are regulated according to customary law. The Customary Territory Registration Agency (BRWA) has identified 9.3 million hectares of customary land in Indonesia. Within these customary territories, there can be land, forests and waters whose regulation and use are regulated based on customary law. The existing regulations are still sectoral in nature, such as the UUPA mentioning ulayat rights, but they do not mention the recognition of the area that 
binds space. This is also what is found in the Forestry Law, which mentions customary forests alone.

\section{b) Right to Spiritual Culture}

This cultural-spiritual dimension is recognized in the "Cultural Identity of Indigenous Peoples", while in the socio-anthropological sense it is known as local wisdom. More specifically, the relationship between indigenous peoples and their customary territories and spiritual dimensions is also known as Local Trust (Penghayat Kep Trust). Ancestral religions that are still practiced today include Parmalim (North Sumatra), Kaharingan (Kalimantan), Sunda Wiwitan (West Java), and Marapu (Sumba).

In Article 28 paragraph 1 of the 1945 Constitution which recognizes the existence of the Identity of the Indigenous Peoples, which is then further elaborated in Article 6 paragraph 2 of Law No.39 of 1999 concerning Human Rights, which states that "The identity of indigenous peoples, including rights to land. ulayat is protected, in line with the times. This right was also emphasized in the Constitutional Court Decision No.97 / PUU-XIV / 2016 (MK 97/2016) which reviewed Law No. 24 of 2013 concerning Amendments to Law No. 23 of 2006 concerning Population Administration.

\section{c) Indigenous Women's Rights}

The rights of indigenous women have a special character and are different from those of women in general. The rights of indigenous women are indivisibility, which means that in a customary women's identity there is a relationship of rights that cannot be separated from one another. Indigenous women as one identity have rights as citizens, individual rights for customary women, collective rights for customary women and collective rights as part of indigenous peoples including collective rights in aspects of cultural expression and traditional occupation. Collective rights that indigenous women have are the identity of the indigenous peoples themselves. The collective rights of indigenous women can be seen from the daily lives of indigenous women which are closely related to knowledge, management areas and authority.

This collective right is the foundation for indigenous women to sustainably ensure their role for indigenous peoples and the State in the form of: (1) Guarding knowledge of food sovereignty and energy for families and communities; (2) The holder of authority over the sustainability of life and sources of livelihood for his family and customary community; (3) Recognition of customary women's management areas that are closely related to the sources of livelihood that ensure the survival of indigenous peoples. This right is what gives rise to a special character in daily practice. In fulfilling their daily needs, women do very specific types of work, namely picking, collecting or quoting natural resource products (forests, gardens, fields, etc.). Local knowledge, such as health, weaving, seeds and food. These characteristics require attention and fulfillment of special needs for the rights of indigenous women.

\section{d) Rights of Indigenous Children and Youth}

Children and youth get special attention because of their specific needs than adults, apart from the existence of power relations that position children and youth as the key to the next generation of a community. The education system and curriculum have also not provided 
room for children, as the next generation of their culture, because they are not contextual. This situation was exacerbated by the loss of their life area.

\section{e) The Right to the Environment}

For indigenous peoples, the environment (milleu) is not only a home for various species of biodiversity, especially those that are endemic. Various medicinal ingredients are available, making the pharmacy alive. The environment is a source of life and knowledge for indigenous peoples so as to produce inherent local knowledge and wisdom and become its own culture and spirituality. This knowledge and skills should be protected by law. Law 32/2009 on Environmental Protection and Management (PPLH), for example, recognizes that indigenous peoples have knowledge in managing land, so there is an affirmative article that provides exceptions for burning forests and land which are regulated in the explanation, namely the local wisdom referred to in this provision is Burning land with a maximum area of 2 hectares per household to plant local varieties and surrounded by firebreaks to prevent fire from spreading to the surrounding area (Article 69). In practice in the field the provisions of this explanation do not apply. On the other hand, the Government considers forests and trees as commodities and becomes the backbone of the economy through various policies, and delegates large-scale forest management to non-state actors. Biodiversity is converted into monoculture plants, which have an impact on destroying the culture and spirituality of indigenous peoples.

\section{f) Right to Participation (FPIC)}

The most essential aspect of community participation is the consent (consent based on awareness) of the parties involved in the participatory process. With consent, the community can make the best decisions for themselves, and understand the consequences of the choices made. For this reason, there are prerequisites that must be met to reach consent. First, there is adequate information provided prior to changes, usually at the planning stage. Second, Adequate time to manage and understand existing information, and Third, an equal participation process, and accommodate the special needs of vulnerable groups.

\subsection{The View of the 1945 Law on Indigenous Peoples}

The 1945 Constitution of the Republic of Indonesia in Article 18B paragraph (2) has guaranteed the existence of indigenous peoples by providing conditional recognition. The recognition of the existence of customary law communities based on Article 18B of the 1945 Constitution serves as a guideline for recognition as well as a form of legal protection for the existence of customary law communities in Indonesia. This recognition means that customary law communities are recognized and protected as legal subjects and their traditional rights. In fact, this form of recognition is found in various government activities, especially activities related to the existence of customary law communities. It also includes recognition of the rights of customary law communities in the use of natural resources, in terms of forest management to obtain optimal benefits from forests and forest areas for the welfare of the community.

In addition to guaranteed recognition of their existence, indigenous peoples also receive constitutional guarantees for Indonesian culture. This is contained in Article 32 of the 1945 Constitution. The State highly respects and maintains regional languages, as cultural assets in 
Indonesia are very diverse. As is known in almost every river flow, language and culture there must be differences. Thus the customary law community has a constitutional basis to defend their rights as contained in these articles.[9]

Meanwhile, as stated in Article 28I paragraph (3) of the 1945 Constitution, the cultural identity and rights of traditional communities are respected in accordance with the development of times and civilization. These statements are official decrees showing that no indigenous group is forgotten or allowed to be left behind in the development process. In this regard, Indonesia is bound by international commitments regarding the recognition of the rights of Indigenous Peoples. On 13 September 2007, the Government of Indonesia also signed the United Nation Declaration on The Rights of Indigenous Peoples (UNDRIP) which mandated that Indigenous Peoples have the same rights regarding livelihoods, education, maintaining identity, and free from all forms of discrimination.[1]

\section{Conclusion}

The existence of indigenous peoples in Indonesia is one of the characteristics and assets of the State that should be protected. Indigenous peoples are understood as Indonesian citizens who are born, live and live in the outermost, deepest and remote areas. They are often isolated from the modernity of life but actually have the same rights as Indonesian citizens who live and live in cities or other places. The four general characteristics of indigenous peoples, namely religious magic, communal, concrete and cash are inseparable characteristics of the lives of indigenous peoples. The existence of indigenous peoples should be respected by today's modern society. State responsibility is not only related to administration and its relationship with the state, but also efforts to fulfill and protect the rights of indigenous peoples.

\section{Refernce}

[1] Kementrian Perencanaan Pembangunan Nasional/Badan Perencanaan Pembangunan Naional Tahun 2003, Masyarakat Adat di Indonesia: Menuju Perlindungan Sosial yang Inklusif. Jakarta: Direktorat Perlindungan dan Kesejahteraan Masyarakat Kementeriaan PPN/Bappenas, 2013.

[2] Saafroedin Bahar, Seri Hak Masyarakat Hukum Adat: Inventarisasi Dan Perlindungan Hak Masyarakat Hukum Adat, Komisi Nasional Hak Asasi Manusia. Jakarta, 2005.

[3] Syarifah M, "Eksistensi Hak Ulayat atas Tanah dalam Era Otonomi Daerah pada Masyarakat Sakai di Kabupaten Bengkalis Propinsi Riau,” USU, 2010.

[4] Husen Alting, Dinamika Hukum dalam Pengakuan dan Perlindungan Hak Masyarakat Hukum Adat Atas Tanah. Yogyakarta: Laksbang Pressindo, 2010.

[5] Sandra Moniaga, Hak - Hak Masyarakat Hukum Adat dan Masalah Kelestarian Lingkungan Hidup, Wacana HAM. Jakarta, 2002.

[6] Ade Saptomo, Hukum \& Kearifan Lokal-Revitalisasi Hukum Adat Nusantara. Jakarta: Grasindo, 2010.

[7] A. D. Anindita, "Sebuah Model Pendidikan Berbasis Komunitas.” Disampaikan Pada Focus Group Discussion Penyusunan Rekomendasi Strategi Kebijakan Pemberdayaan Sosial Masyarakat Adat Yang Terintegrasi. Diselenggarakan oleh Direktorat Perlindungan dan Kesejahteraan Masyarakat,” 2013. . 
[8] "Hak-Hak Masyarakat Adat - merDesa Institute." .

[9] "Keberadaan Hukum Adat Dijamin UUD 1945 | Republika Online.". 